\title{
A plantation-dominated forest transition in Chile
}

\section{Keywords}

Chile, forest transition, plantation forestry, land use change, remote sensing

\section{Abstract}

As one of the few countries in Latin America to have reversed persistent losses in tree cover, Chile may hold important insights for forest transition theory. However, existing studies have not provided methodologically consistent analyses at sufficient temporal and spatial scales to properly assess the state of Chile's forest transition. In the current study, we generate high-resolution maps of Chilean land use change between 1986, 2001 and 2011. We couple remote sensing with a review of historic assessments of Chile's forest resources to document long-term trends in forest extent. This historical review identified multiple discrete forest transitions throughout Chile's history. These fluctuations in forest clearing emphasize that the cultural, economic and political forces that precipitate forest transitions can all be reversed. The remote sensing analysis calls into question official statistics indicating an expansion of native forests between 1986 and 2011. We find that increases in forest cover were largely driven by the expansion of forest plantations, rather than through native forest regeneration. Plantation forests directly displaced native forests in many locations, especially during the 1986-2001 period. Nevertheless, declines in the rate of forest conversion during the 2001-2011 period may suggest that plantations are beginning to ease pressure on native forests.

\section{Graphical abstract}

Central-Southern Chile: Land use in 1986 and 2011

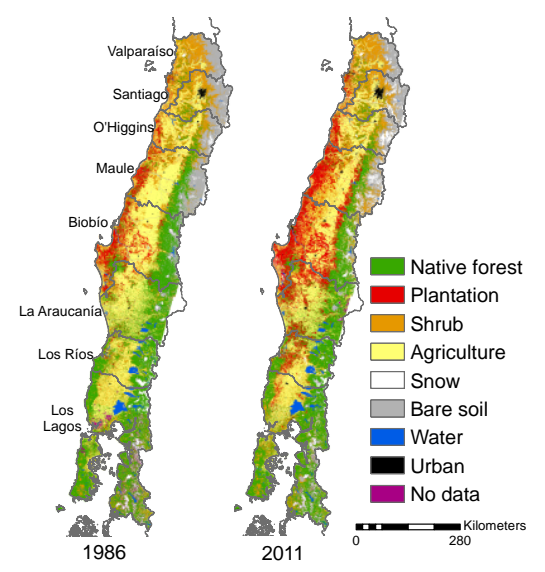

Conversion to plantations and from forests between 1986 and 2011

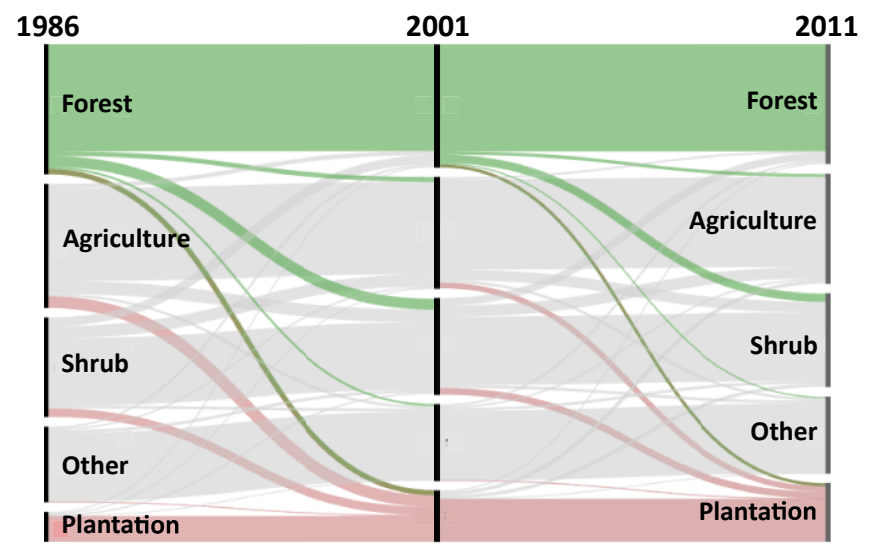




\section{Introduction}

Over the past decade, decelerating deforestation and forest expansion in some countries have fostered growing public optimism that the world may be discovering ways to end deforestation (Rosenthal 2010; Nepstad et al. 2009; Meyfroidt and Lambin 2011). In response, land systems scientists have shown a great deal of interest in understanding the processes that give rise to forest expansion. In particular, forest transitions - national shifts from extended periods of deforestation to periods of forest expansion - seem to be an important factor in current global forest trends (Mather 1992). Early studies of forest transitions sought to describe historical changes in the extent of temperate forest cover in Europe and North America (Mather, Fairbairn, and Needle 1999; Mather and Fairbairn 2000). However, a growing literature focuses attention on more recent transitions in Asia and Latin America (Meyfroidt and Lambin 2008; Nagendra and Southworth 2009; Bruggeman, Meyfroidt, and Lambin 2016). Developing countries that have successfully reversed longstanding trends of deforestation may hold insights to guide more sustainable land use practices.

However, forest transition analyses that aggregate distinctly different types of tree-covered landscapes under a single definition of forests may obscure the ecological impacts of continued changes in forest composition and location (Perz 2007). China, for example, has added nearly three million hectares of forest annually over the past decade as result of aggressive reforestation efforts (FAO 2011). Although FAO statistics indicate that the extent of primary forests has not declined, diverse native forests are being converted to plantation monocultures (Li et al. 2006). Furthermore, much afforestation has taken place without consideration of the local suitability of planted species (Xu 2011). Such examples highlight the importance of assessing the ecological quality of forest transitions (Lambin and Meyfroidt 2010).

An increasingly important determinant of the ecological quality of forest transitions is the relative share of plantation and natural forests (Hall et al. 2012). Due to rapid growth over the past two decades, plantations now constitute more than 7 percent of global forest area (FAO 2010b). This rapid growth in plantation area has been associated with a variety of political, demographic and economic drivers (Rudel 2009). This expansion has allowed the world to meet rapidly growing demand for timber and fiber; by 2020, plantations are estimated to provide 44 percent of global industrial roundwood production (Carle, Vuorinen, and Del Lungo 2002). Plantation forests also serve as an important component of global strategies for carbon emissions mitigation (Favero and Mendelsohn 2014; Strengers, Minnen, and Eickhout 2007). However, while plantations may reduce harvest pressure on natural forests, they also directly compete for scarce land (Heilmayr 2015). When plantations displace native forest ecosystems, 
they can reduce biodiversity (Barlow et al. 2007; Stephens and Wagner 2007), introduce invasive species (Richardson 1998, 199), negatively affect local hydrology (Jackson et al. 2005; Little et al. 2009) and increase erosion (Oyarzun and Peña 1995). As a result, it is important to understand the types of ecosystems forest plantations replace.

The ecological differences between plantations and naturally occurring forests have inspired the term "tree-cover transition" as a more general variant of the traditional "forest transition" (de Jong 2010; van Noordwijk 2014). Such terminology enables clear differentiation between "natural" forest regrowth (forest transitions) and more anthropogenically driven tree-cover expansion (tree-cover transition). However, to maintain consistency with the original literature on forest transitions, we choose to follow the FAO definition of forests in which "forest area" includes both naturally occurring and plantation forests. We nevertheless strive to provide a more nuanced description of Chile's forest transition by differentiating "plantations" from "native forests" throughout our analysis. We choose to use the term "native forests" to refer to non-plantation forests in order to maintain consistency with Chilean terminology. Following this convention, we use the term native forest transition to refer to increases in native forest area, and forest transition to refer to increases in the sum of plantations and native forests.

The objective of this study is to analyze forest expansion in Chile, one of the few countries with net gains in tree cover that has rarely been explored through the lens of forest transition theory. Whereas government datasets (CONAF, CONAMA, and BIRF 1999; CONAF 2008) and UN FAO's Global Forest Resource Assessment (FRA) (FAO 2010b) indicate that Chile has undergone a forest transition, several regional analyses emphasize the continued loss of native forests (Clapp 2001; Echeverria et al. 2006; Lara et al. 2012; Echeverría et al. 2012). In order to reconcile these inconsistencies, we undertake the most spatially and temporally comprehensive, methodologically consistent analysis of land use change in Chile to date. The results overturn the existing understanding of Chile's forest transition by identifying net losses in native forests between 1986 and 2011. In addition, a review of Chile's historic forest extent underscores the precarious nature of forest transitions. Finally, this study adds nuance to forest transition theory by differentiating changes in the area of native forests and plantation forests.

\subsection{Study area}

Chile has many characteristics that make it a particularly important subject for forest transition research. Historical isolation, shaped by geographic influences of the Andes, Atacama Desert and Pacific Ocean, has endowed Chile with exceptionally high levels of endemism (Smith-Ramírez 2004). Extreme gradients in elevation and latitude have further contributed to the country's impressive biodiversity 
(Armesto, Villagrán, and Arroyo 1996). However, timber harvests and agricultural expansion from the $18^{\text {th }}$ until the early-20 $0^{\text {th }}$ century led to significant degradation of forest ecosystems (Armesto et al. 2010).

As one of very few Latin American countries to have seemingly reversed persistent losses in forest cover, Chile may hold important lessons to guide the creation of effective mechanisms to slow global deforestation. Rising incomes, labor diversification and government policies have all influenced forest expansion (Modrego, Barrera, and Charnay 2004; Diaz et al. 2010). Due to the rapid growth of plantations, Chile can also inform our understanding of the environmental impacts associated with forest-sector intensification. Plantations provide nearly 95 percent of the country's timber production on 15 percent of its forested lands (FAO 2010; FAO 1997). Such intensive production has the potential to reduce pressures on native forests. However, plantation expansion has also been an important direct driver of native forest clearing (Clapp 2001; Echeverria et al. 2006). As a result of these competing interactions, the ecological impacts of Chile's forest transition are unclear. Careful consideration of Chile's experience may give forest transition theory greater nuance in describing the range of possible ecological consequences of forest expansion.

Due to the forest sector's connections to the neoliberal economic policies of the 1970's, Chile's experience holds significant relevance in a steadily globalizing economy. In contrast to other countries undergoing forest transitions, Chilean forest expansion has occurred with relatively little import-based displacement of land use to other countries (Meyfroidt, Rudel, and Lambin 2010). With timber products and pulp counting among its top exports, Chile can provide insights into trade's impacts on natural resource protection. The recent expansion of the Chilean forest industry into countries such as Argentina, Brazil and Uruguay further highlights the potential importance of the Chilean forestry model for the rest of the world.

\subsection{Historical transitions}

Over the course of its human history, Chile has undergone a series of alternating periods of deforestation and forest expansion. By the time Spanish explorers reached Chile's shores, agricultural mosaics existed in many of the more fertile regions of the country (Camus and Solari 2008). Although the 'original' extent of Chilean forests may have approached 30 million hectares (Bryant, Nielsen, and Tangley 1997), archeological reconstructions indicate that indigenous populations had converted nearly 891,000 hectares of forests over much of Central and Southern Chile to agricultural mosaics (Lara et al. 2012). However, Spanish conquest and the associated introduction of disease devastated the indigenous population throughout this region. The ensuing three hundred years of Spanish colonialism mark Chile's 
first native forest transition. By the middle of the $19^{\text {th }}$ Century, Chile's native forests had reclaimed many abandoned agricultural areas and covered approximately 24 million hectares (Otero 2006).

After the Chilean War of Independence (1810-1826), the newly established government began to shift its attention towards consolidation of its territory. Through a combination of incentives, immigration reforms and infrastructure investments, the government encouraged widespread colonization during the second half of the $19^{\text {th }}$ century. According to Federico Albert, the first Chilean Inspector General of Forests, Hunting and Fishing, 13 million hectares (approximately half) of Chile's forests were cleared during this period of colonization. Although Albert claims the total forested area in 1914 was 15.7 million hectares, his estimates for the Patagonian region of Magallanes is considered an overestimate by several million hectares. Albert's revised numbers indicate that the total area of forests fell from between 24 and 29 million hectares in the mid-1800s to between 11 and 16 million hectares by 1914 (Albert 1901; Albert 1913; Otero 2006). Despite the uncertainty of Albert's estimates, the observation of significant Chilean deforestation during the Southern colonization is confirmed by the country's first aerial inventory of forest resources. The maps created by the US Forest Service's Chilean Forestry Mission in 1946 document just 10.9 million hectares of forests and woodlands (Haig et al. 1946). In the aftermath of the Great Depression and World War II, Chile began to pursue a policy of import substitution and industrial support. The policies pursued generally discriminated against domestic agricultural production - increasing the cost of agricultural inputs while lowering the cost of imported agricultural products. Agricultural production stagnated as a result of these discriminatory policies and the relative inefficiency of Chilean agriculture (Silva 2007). The slow recovery of agricultural production appears to have driven an expansion of native forest cover in the middle of the $20^{\text {th }}$ Century. In addition to forest regeneration on abandoned agricultural lands in Central Chile, Southern Chilean forests recovered during this period on formerly burned landscapes (Otero 2006). Although inconsistencies in definitions across different assessments complicate direct comparisons, a variety of studies by FAO and Chile's national forestry institute (INFOR) indicate native forest extent reached a peak of approximately 14 million hectares between the late 1950's and 1980 (INFOR 1986a).

In addition to disincentivizing agriculture, Chilean import substitution encouraged the establishment of industrial forest plantations through tax incentives and public investments (Clapp 1995). Haig et al. (1946) observed 143,500 hectares of plantation forests throughout the country; fifty-eight percent was composed of Pinus radiata and 31 percent of Eucalyptus spp. In the following decades, plantations of non-native species continued to expand, first due to direct government investment, and then 
increasingly through the private sector during the Pinochet regime. Trade liberalization and the 1974 passage of Decree Law 701 (D.L. 701) - a package of policies that protected reforested landscapes from expropriation and subsidized $75 \%$ of afforestation costs on new plantations - are often identified as important drivers of the rapid expansion of Chilean plantations in the last quarter of the $20^{\text {th }}$ century (Niklitschek 2007; Gonzalez 2010; Nahuelhual et al. 2012). Chilean plantations covered 740,000 hectares in 1980; ten years later that area had more than doubled to 1.7 million hectares (FAO 2010b).

A variety of regional case studies in Chile link this rapid expansion of plantation forestry to a new period of native deforestation. In the Mediterranean dryland forests near Santiago, fuelwood harvesting and conversions to plantations between 1975 and 2008 led to the loss of 82,000 hectares of forests, or more than a third of original forest extent (Schulz et al. 2010). In the Coastal forests of Chile's Maule and Biobío Regions, more than two thirds (81,000 has) of all forests were lost between 1975 and 1990, primarily due to agricultural and plantation expansion (Echeverria et al. 2006). In the central valley and Andean foothills of Maule and Biobío, 20 percent (132,000 has) of native forests were converted to plantations between 1979 and 2000 (Aguayo et al. 2009). Conversion to plantations drove the majority of native forest loss between 1987 and 2008 (Miranda et al. 2015). Between 1986 and 2001, 6 percent $(98,000$ has) of the native Valdivian rainforests in parts of the Southern regions of Los Ríos and Los Lagos were converted to plantations (Holt et al. 2012). Such clearing for plantation forestry was an important driver of broader native forest loss in the final decades of the $20^{\text {th }}$ Century. At the national scale, an update to INFOR's 1980 study found that half a million additional hectares of forests had been cleared by 1995 (INFOR and CORFO 1996).

\subsection{Contemporary forest transition}

The commonly-held belief that Chile is currently undergoing a forest transition stems primarily from the aggregate forest cover statistics presented in the UN FAO's Global Forest Resource Assessment (FRA) (FAO 2010b). The FRA indicates that over the past 20 years, both natural and planted forests have expanded in Chile. Since the FRA data largely represents self-reported government forest statistics, it is not surprising that the Chilean government's own analyses of land use demonstrate a similar expansion of both native and plantation forests (CONAF, CONAMA, and BIRF 1999; CONAF 2008).

However, the national-scale statistics generated by the government lie in contrast to several analyses published in the academic literature. Clapp (2001) posits that the 1990s represented the "most rapid deforestation in Chile's history." A variety of regional analyses have encouraged a common perception among Chilean land system scientists that, while plantation forests have certainly expanded, this 
expansion has likely resulted in a significant decline in native forests (Echeverria et al. 2006; Lara et al. 2012). Non-governmental organizations have built on the academic research to further question the accuracy of government forest data (Fredes 2002; La Nación 2011).

In attempting to make sense of the seemingly inconsistent findings between academic and government research, several limitations of the existing research become apparent. Although the government's assessment has been used to determine general trends in land use, precise determination of land use transitions are not possible due to poor georegistration and a lack of consistency in methods across time. Government updates to the cadaster state that perceived land cover changes resulting from the comparison of cadasters from different points in time primarily represent methodological improvements or changes in definitions rather than actual changes in land use (CONAF 2011; CIREN 2013; CONAF and Universidad Austral de Chile 2014). In addition, the government cadasters only provide assessments of land use in the late 1990s and 2011. They miss many of the important changes in land use that occurred towards the end of the $20^{\text {th }}$ century. In contrast, academic analyses of land use change have generally been limited to specific regions exhibiting prominent land use change patterns (Echeverria et al. 2006; Aguayo et al. 2009; Diaz et al. 2010; Schulz et al. 2010; Altamirano and Lara 2010; Echeverría et al. 2012; Nahuelhual et al. 2012). These studies are inadequate for determining large-scale patterns in land use change. Global, high-resolution remote sensing products (Hansen et al. 2013) achieve the desired scale and consistency in methods, but a lack of differentiation between natural and planted forests and a short time series (2000-2012) limit their value in describing Chile's forest transition. In the current study, we undertake a consistent, high resolution assessment of land use change across Central-Southern Chile between 1986 and 2011. Using this data, we determine whether native and plantations forests have expanded. We also explore the implications of these patterns through the lens of forest transition theory.

\section{Materials \& methods:}

\subsection{Study area boundaries}

The study boundaries were defined as Chile's Valparaiso Region in the North and the Los Lagos Region in the South (Error! Reference source not found.). The study area covers only 28 percent of Chile's land, but it includes almost all forested landscapes facing potential conversion to other land uses. Landscapes further to the north are generally incapable of supporting forests, and those to the south are sparsely populated and relatively inaccessible. We divided the study area along regions, Chile's first 
administrative division. Chile's regions are arrayed from north to south in a transect of Chile's extreme latitudinal gradient. The northern regions in the study area (Valparaíso, Santiago, O'Higgins) experience a Mediterranean climate. These regions include many of the most urbanized parts of Chile, as well as the highest value agricultural lands. The central regions in the study area (Maule and Biobío) experience a more temperate climate and are the center of Chile's forestry industry. The greater precipitation falling in the southern regions (La Araucanía, Los Ríos and Los Lagos) gives rise to extensive temperate forests. These regions also include extensive rotations of livestock and grain production.

\subsection{Data selection \& pre-processing}

To capture changes in land use at a fine spatial resolution over multiple decades, we chose Landsat imagery as the principal data source for the remote sensing analysis. Cloudless, summer-season images with acquisition dates within two weeks of the anniversary date of the other images for that scene were selected whenever possible. In total, 42 images we collected to cover fourteen Landsat scenes at each of three time periods (1985-1987, 1999-2001 and 2009-2011). The dates selected for each path and row are listed in Table A-1. When multiple adjacent scenes along the satellite's path were available from a single day, these images were merged into a single image to reduce the number of separate images from 42 to 28. The sources of the data included the United States Geological Survey (USGS), the Argentinean National Space Activities Commission (CONAE) and Brazil's National Institute for Space Research (INPE).

We relied upon semi-automated processes for all stages of analyses due to the large quantity of imagery required for the research. Georegistration of images was conducted using the Automated Precise Orthorectification Package - AROP (Gao, Masek, and Wolfe 2009). AROP parameters were set to yield root mean square errors for georegistration accuracy of less than one pixel. Calibration, atmospheric correction and conversion to surface reflectance were completed using the Landsat Ecosystem Disturbance Adaptive Processing System - LEDAPS (Masek et al. 2006). Because of the complex topography of many regions within the study area, topographic shadows could pose a problem for consistent classification. As a result, we corrected surface reflectance using a semi-empirical Teillet Ccorrection (Teillet, Guindon, and Goodenough 1981; Meyer et al. 1993) implemented in Python. Using indicative maps of forested areas (CONAF 2008), we drew a sample of 10,000 forested pixels within each Landsat scene. We then used these points to develop scene- and band-specific regression models of surface reflectance in forested areas as a function of the solar incidence angle. We then applied these regressions to create corrected images which minimized topographically induced dissimilarities in 
reflectance values. A similar procedure has been shown to improve the quality of classification in mountainous regions (Balthazar, Vanacker, and Lambin 2012).

\subsection{Change vector analysis}

Topographically corrected surface reflectance data for all images were processed using a tasseled cap transformation (Crist 1985) to generate brightness, greenness and wetness bands. Similar to the change vector analysis proposed by Lambin and Strahlers (1994), change was assessed for each pixel by computing the Euclidean distance across time in three-dimensional tasseled cap space. Since the focus of this study was to identify changes in forest cover, we further modified the change vector analysis to accentuate the greenness band. We did this by standardizing the difference raster of each of the tasseled cap bands and rescaling the green band by a factor of two prior to taking the three-dimensional Euclidean distance. This rescaling accentuated differences in vegetation and made the spectral change bands more sensitive to nuanced spectral changes in land use such as the conversion of native forests to plantations. We used expert photointerpretation to determine change thresholds for each scene to generate binary rasters identifying regions where land cover change had taken place. Particular attention was placed on ensuring these thresholds would capture spectrally nuanced changes such as forest regeneration, or conversion from native forests to plantations. The resulting binary maps of spectral change were used for two purposes: to limit historical classification samples to spectrally stable pixels (see Section 2.4) and to conduct a hybrid change detection across the study area (see Section 2.6).

\subsection{Generation of dataset for classification model training and testing}

We conducted a supervised maximum likelihood classification of land use on each of the 28 images. Using the government's land cover cadaster for stratification (CONAF 2011), points were randomly sampled from each scene to yield examples of each of 16 classes (adult forest, secondary forest, stunted forest, adult plantation, young plantation, clear-cut, shrub, arboreous shrub, wetland, cropland, fallow, grassland, bare ground, urban, snow and water). Based on calculations outlined by Congalton and Green (2009), we sought to generate at least 55 points in each land use class for each image to be classified. In total, more than 11,000 points were sampled across the study region.

A combination of Google Earth imagery and field visits were used to classify samples into each of the 16 land use classes. To ensure comparability to existing studies of land use in Chile, we used official government definitions for each of our land use classes (FAO 2010a; CONAF and CONAMA-BIRF 1995). Adult forests included regions in which native tree species reached a height greater than 8 meters, and 
the canopy covered at least 25 percent of the area. Secondary forests included regions with native tree species exceeding 2 meters and a canopy cover of at least 25 percent. In contrast to adult forests, trees in secondary forests exhibit relatively high homogeneity in age, vertical structure and diameter. Stunted native forests, also known as achaparrado or krummholz, included groupings of tree species that were limited in growth (heights between 2 and 8 meters) due to exposure to strong winds or poor soil. Plantations included areas in which exotic trees (primarily Eucalyptus Globulus and Pinus Radiata) had a canopy cover of at least 25 percent. Given Chilean forestry practices, the highly homogeneous, intensively managed plantation monocultures tended to yield plantations with a spectral signature that was distinct from native forest classes. Formal definitions of each of our land use classes are provided in Appendix B.

In order to minimize misidentification due to small errors in georegistration (Stehman and Wickham 2011), we segmented images into spectrally similar, multi-pixel polygons using e-Cognition software. Each randomly sampled point was associated with the overlaying polygon to create a sample of multipixel polygons used for classification training and testing. In order to minimize the impact of mixed landuse polygons, only polygons of a single land cover class were used for model training. To avoid biasing the error calculation, mixed polygons were retained for model validation. In such cases, the individual pixel was used for accuracy assessment rather than the full mixed polygon.

Since high resolution Google Earth imagery was generally limited to the most recent time period, the binary change maps derived from the tasseled cap bands were used to identify spectrally stable samples. Stable samples were used to train and test the classification of older Landsat scenes. Where possible, we used external historical datasets including aerial imagery, historical maps of plantation concessions and the Chilean government's land use cadaster to refine training data or conduct postprocessing revisions to the classification (CONAF, CONAMA, and BIRF 1999; CONAF 2008; INFOR 1986b; INFOR 2009).

\subsection{Classification model estimation and cross-validation}

The sample polygons were used for both training and testing of the classification algorithm through a five-fold cross-validation. We randomly separated all sample data into five groups. The classifier was trained using four of the five groups, while accuracy assessment was conducted using the last group. The input data for the classification model included all of the atmospherically and topographically corrected Landsat image bands, as well as topographic information from the Global Land Survey Digital Elevation Model (USGS 2008). This procedure was repeated using each of the five groups as the test 
group. The accuracy measurements from each iteration were then combined to yield an accuracy assessment for the entire classification procedure. Finally, the classification was repeated one more time using all samples to generate final land use maps.

After classification, several land use classes were merged in order to simplify the final analysis and meet desired levels of accuracy. The resulting classes were native forest (adult, secondary and stunted), forest plantation (young, adult and clear-cut), shrub, agriculture (including crops and pasture land) and other (bare soil, snow, water and urban). Based on these aggregated classes, we calculated confusion matrices and the associated kappa coefficient of agreement for each image. We combined these accuracy matrices with the classified maps to generate error-adjusted estimators of the area of each land cover class at each point in time (Olofsson et al. 2013).

\subsection{Hybrid change detection}

In order to determine the trajectory of change while avoiding the decline in accuracy resulting from traditional post-classification change detection methods, we used a hybrid change detection method (Coppin et al. 2004). First, binary maps differentiating changed from unchanged pixels were derived from the tasseled cap bands. The post-classification comparison of two points in time was then used to characterize the specific land use transition for each pixel.

\subsection{Comparison to previous datasets}

In order to explore differences across datasets, we compared our estimates of forest cover change to previous analyses of forest cover in Chile. Limiting our comparisons to public, spatial datasets that spanned our study region, we compared our results to forest cover statistics derived from the official government cadaster (CONAF 2011) and version 1.2 of Hansen et al.'s global dataset (2013). Since we used the same land use class definitions as the government cadaster's 2011 classification, the comparison to these maps was relatively straightforward. We limited the area of analysis to the region included in our study, and then aggregated the total area in native forest classes (adult native forest, secondary native forest and stunted native forest) and plantation classes (adult plantation, young plantation) for each of the two periods of the cadaster (1997 and 2011). Hansen et al. (2013) provide $30 \mathrm{~m}$ resolution rasters of percent tree cover in 2000, and binary forest gain between 2000 and 2012, and annual forest loss for each year between 2000 and 2014. To calculate the forest extent in the year 2000, we determined the area of land with forest cover exceeding 25 percent - the same cutoff used for forests in the cadaster and in this study. To calculate the net forest change between 2000 and 2012, we took the difference between the total forest gain and total forest loss over the study region. We did not 
count forest loss on pixels that started with less than 25 percent forest cover. Our year 2012 estimate of forest extent was the sum of year 2000 forest area and this calculation of net changes in forest extent.

\section{Results}

\subsection{Land use classification}

At a national scale, Chile's general land use patterns are strongly influenced by longitudinal topographic gradients and latitudinal climactic gradients (Error! Reference source not found.). Moving across the study area from West to East, one crosses from the Pacific Ocean, over a coastal mountain range, through a broad central valley and into the Andes. In general, the most productive agricultural lands fall within the central valley, while forestry plays a more important role in the coastal range and the foothills of the Andes. Transecting the study area from North to South, the dominant trend is a shift from a Mediterranean climate in Valparaiso and O'Higgins, through a temperate climate in Maule, Biobío and La Araucanía and into a temperate rainforest in Los Ríos and Los Lagos. As a result, the natural vegetation shifts from Mediterranean shrub and sclerophyllous forests in the North to more dense and expansive temperate rainforests in the South. This latitudinal gradient can be seen in the depiction of regional land use shares presented in Error! Reference source not found.

The accuracy of these maps is presented in the form of confusion matrices in Table 2. Cohen's Kappa for the three time periods was 0.83 for the 1986 map, 0.81 for the 2001 map and 0.82 for the 2011 map. Classification accuracies for native forests ranged from 88 to 91 percent, while accuracies for plantations ranged from 79 to 90 percent. Using the confusion matrices, adjusted area estimates and confidence intervals were calculated for each land use (Error! Reference source not found.).

\subsection{Forest area changes}

Plantation forests underwent rapid expansion throughout the study period. Between 1986 and 2001, plantation forests expanded at a rate of 4.3 percent per year, nearly doubling the total area of plantation forests to 2.3 million hectares. ${ }^{1}$ While the rate of expansion slowed to 2.2 percent in the 2001 to 2011 period, the country still added 573 thousand hectares of additional plantations. Throughout the study period, plantations were primarily established on former agricultural lands (45.1 percent) and shrub (31.0 percent). Nevertheless, native forests were also an important source of land for plantations;

\footnotetext{
${ }^{1}$ Annual rates of change are calculated using the FAO's compounding growth formula.
} 
22.3 percent of all new plantations were established on lands that had been native forests in 1986 (Error! Reference source not found.).

Between 1986 and 2011, the total area of native forests declined by 0.3 percent annually. However, this decline obscures different trends in the two time periods. Between 1986 and 2001, the annualized net rate of native deforestation was 0.5 percent between 1986 and 2001, dropping to 0.1 percent between 2001 and 2011. In addition, the gross rate of native deforestation was three times higher than the net rate of native deforestation. Although the total native forest area in 2011 represented 92 percent of the total native forest area in 1986, only 77 percent of the native forests that had been standing in 1986 still persisted as native forests in 2011. This difference is consistent with recent studies that have emphasized the dynamism and reversibility of land use change in southern Chile's forested landscapes (Altamirano et al. 2013; Carmona and Nahuelhual 2012). Error! Reference source not found. illustrates the transitions back and forth between native forests and other land uses.

The proximate causes of native forest loss varied dramatically by region. In the Northern regions bordering metropolitan Santiago (Valparaiso, O'Higgins and Santiago Metropolitan), forests were primarily degraded to Mediterranean shrub. In Maule and Biobío, the heart of the Chilean timber industry, the majority of forest conversion was caused by plantation expansion. In these regions, 16.3 percent of native forests standing in 1986 had been converted to plantations by 2011. While plantation expansion also played an important role in forest clearing in La Araucanía agricultural expansion was the dominant driver of clearing. Finally, in the temperate rainforests of Los Ríos and Los Lagos, conversion to shrub was the primary proximate cause of forest loss. In these regions, the largest contiguous conversions were the result of fire on Chiloe Island, and the eruption of Chaitén volcano in Continental Chiloe. In contrast, the dominant transition leading to forest regrowth was fairly consistent throughout the country - secondary regrowth occurred overwhelmingly in shrub and, to a lesser extent, agricultural lands.

The aggregate changes in native and plantation forests indicate significant expansion of forested landscapes. The net increase in native and plantation forests between 1986 and 2011 was 1.2 million hectares or 16.1 percent of the total area of forests in 1986. The rate of expansion of total forest area was 0.6 percent per year for both time periods. 
4. Discussion

\subsection{Precarious forest transitions}

Historically, Chile has undergone multiple forest transitions. Early Spanish colonialism drove a dramatic decline in population, resulting in agricultural mosaic abandonment and an associated expansion of secondary forests. The causes of this native forest transition eventually led to a later period of extensive deforestation as the Spanish colonial state expanded into the Southern portions of Chile. Although definitions of forests vary across existing estimates from the first half of the 1900s, our synthesis of data indicates a second forest transition occurring in the middle of the 20th Century. Finally, the current study confirms a contemporary forest transition that began towards the end of the $20^{\text {th }}$ Century. These multiple transitions emphasize an under-explored precariousness of forest transitions. In the case of Chile, historical changes in economic conditions and policy were associated with shifts in land use trends. This reinforces arguments that forest transitions complicate the clear determination of deforestation baselines (Angelsen 2008). The Chilean experience provides little evidence to indicate that a forest transition represents a permanent shift in land use trends. The persistence of a forest transition will often depend upon the continuation of economic, political and cultural trends that precipitated the original onset of forest transition.

\subsection{Plantation dominated transition}

Our analysis of Chile's forest cover indicates that total forested area consistently increased throughout the study period. Forests comprised 34.6 percent of the studied area in 1986, expanded to 37.6 in 2001, and 40.2 percent by 2011 . However, rather than representing regeneration of native forests, this expansion of forest cover was the result of rapid expansion of plantation forests. In contrast to native forest transitions in other countries in which native forests expanded due to economic development (Mather 1992), forest product scarcity (Foster and Rosenzweig 2003) or smallholder agricultural intensification (Meyfroidt and Lambin 2008), the underlying drivers of Chile's forest transition were more closely related to the political, economic and technological conditions that encouraged industrialization and expansion of Chile's timber sector. Through early investments in forestry research, Chile cultivated a natural advantage in forestry based on highly-productive, short-rotation plantations (Sedjo and Botkin 1997). When coupled with supportive government policies such as subsidies for afforestation (Gonzalez 2010) and trade liberalization (Niklitschek 2007), this natural advantage was exploited to achieve rapid growth in plantation areas (Clapp 1995). Interestingly, the policy interventions and business development that enabled Chile's forest transition were not precipitated by 
inherent local scarcity of forests, but rather by explicit trade objectives that sought to establish Chile as a leader in the global timber sector. These drivers underlie the unique pattern observed in Chile in which a country simultaneously undergoes a forest transition, while expanding its exports of land intensive products (Meyfroidt, Rudel, and Lambin 2010).

The common emphasis on expansion in total forested area obscures important net losses in native forest area that occurred between 1986 and 2011. In contrast to previously published figures on Chilean native forest extent (FAO 2010b; CONAF 2011), we find that the area of native forests declined throughout the study period (Error! Reference source not found.; Table 3). Given that our analysis is the first study at this scale to track changes in plantation and native forest areas using consistent land use definitions and remote sensing methods, we believe our results provide a valid counterweight to previous figures. Despite the contradiction with government statistics, our results are consistent with a variety of studies that have been conducted at more local scales (Echeverria et al. 2006; Aguayo et al. 2009; Schulz et al. 2010; Diaz et al. 2010; Altamirano and Lara 2010; Echeverría et al. 2012).

The majority of regions experienced native deforestation between 1986 and 2001. The highest regionalscale rates of native deforestation between 1986 and 2001 exceeded 1 percent in Maule, Biobío and La Araucaría. Although these rates of native forest loss would rank among the World's highest national rates of deforestation over the same period (FAO 2010b), they occurred during a period where Chile was ostensibly experiencing a forest transition. This result draws attention to the importance of considering forest transitions at multiple scales (Walker 2012), and of characterizing forest types when assessing forest transitions. Many studies of forest transitions that were based on FAO data have treated all forests similarly (Rudel et al. 2005; Meyfroidt, Rudel, and Lambin 2010), but there is a growing awareness that forest transition theory must recognize the important differences between different forest types (Lambin and Meyfroidt 2010; Hall et al. 2012; Angelsen and Rudel 2013).

\subsection{Forest substitution}

Previous analyses have emphasized the important role plantation forestry played as a proximate cause of deforestation in Chile. Lara and Veblen (1993) estimate that between 10 and 20 percent of Chile's pine plantations had been established through the conversion of native forests. In the coastal mountains of Chile's Maule and Biobío regions, Echeverria et al. (2006) find that 53 percent of the native forests were converted to plantations between 1973 and 2000. Consistent with these results, we find significant conversion of native forests to plantations. 14.3, 12.6 and 11.1 percent of forests in Maule, Biobío and La Araucanía respectively were converted to plantations between 1986 and 2011 . The aggregate share 
of forests converted to plantations across our study region is 6.5 percent. However, the rate of conversion of native forests to plantations shows dramatic regional variations. In Los Lagos, the most heavily forested region in the study, only 0.4 percent of native forests were converted to plantations.

In Chile, where plantation forestry generally takes the form of short rotation, even-aged monocultures, the replacement of native forests with plantation forests poses particularly important ecological consequences. Previous studies have emphasized that, in comparison to nearby native forests, Chilean plantations reduce water yields within watersheds (Little et al. 2009) and sequester less carbon in aboveground biomass (Gayoso 2001). In addition, Chilean plantation plots typically have a lower vascular plant species richness, but a higher prevalence of exotic species than matched native forest plots (Frank and Finckh 1997; Becerra and Simonetti 2013). As a result, the ecological quality of Chile's forest transition is likely to be relatively low (Lambin and Meyfroidt 2010).

Although plantation expansion has directly displaced native forests, it also has the potential to benefit native forests through displacement of timber supplies. Clapp (2001) argues that plantation forestry in Chile had failed to deliver on this promise. He notes that the rapid increase in exports of native wood chips in the 1990s demonstrated that the loss of access to traditional timber markets did not lead to a reduction in native forest harvesting. While this seems to be an accurate characterization of Chile's forestry markets in the 1990s, the early 2000s marked a dramatic collapse in native woodchip production. By 2004 , one decade after native woodchip production peaked at 2.8 million cubic meters per year, native woodchip production had been completely replaced by plantation production (INFOR 2008; Lara and Reyes 2008).

This transformation likely enabled several policy changes providing more formal protection of native forests. A law to protect and encourage regeneration of Chile's native forests had been very controversial since the legislation was proposed in 1992 (Clapp 1998). Nevertheless, due to gradual changes in the timber sector, opposition declined and the law was finally adopted in 2008 (Henne and Gabrielson 2012). In addition, in the early 2000s, the Chilean timber sector was transformed through the implementation of a variety of non-state, market driven governance systems. These policies included eco-certification through the Forest Stewardship Council, a competing Chilean certification standard called CERTFOR, and the Joint Solutions Project, a voluntary agreement between environmental organizations and Chile's three largest timber companies. Heilmayr and Lambin (2016) demonstrate that these policies slowed forest substitution. When considered alongside the slowing of native forest 
clearing observed between 2001 and 2011, it appears that plantation forestry, combined with changes in forest policy, have reduced pressure on native forests in the long term.

\section{Conclusion}

Our historical review of forest trends documents three distinct forest transitions: i) a colonial native forest transition associated with indigenous population decline; ii) forest regrowth associated with the import substitution policies of the mid- $20^{\text {th }}$ Century; and iii) a contemporary, plantation-dominated transition. These results underscore the precarious nature of forest transitions. Over long periods of time, the cultural, economic and political forces that precipitate forest transitions can all be reversed. Rapid expansion of plantation forests drove the forest transition at the turn of the $21^{\text {st }}$ Century. In contrast to government statistics indicating native forest expansion, we document continued declines in the area of native forests. Plantation forests directly displaced native forests in many locations, especially during the 1986-2001 period. This conversion of native to plantation forests has had important, adverse ecological impacts. Nevertheless, dramatic declines in the use of native timber in industrial applications, as well as declines in the rate of forest conversion during the 2001-2011 period and changes in forestry policies may suggest that plantations are beginning to ease demand pressure on native forests.

\section{Acknowledgements}

This research was supported by the National Science Foundation Graduate Research Fellowship under Grant Number DGE-1147470, the Robert and Patricia Switzer Foundation, Stanford University's Emmett Interdisciplinary Program for Environment and Resources. Additional financial support for the classification of some satellite scenes and the collection of ground-truth data was provided by Rodrigo Arriagada and by FONDECYT Project 1140531. The Argentinean Comisión Nacional de Actividades Espaciales donated several satellite images from its archive. Elif Tasar, Karla King, Samuel Otavo, Julian Reyes and Julie Scrivner all provided essential assistance at various stages of research. 


\section{Figures}

Figure 1: Political and ecological regions of study area

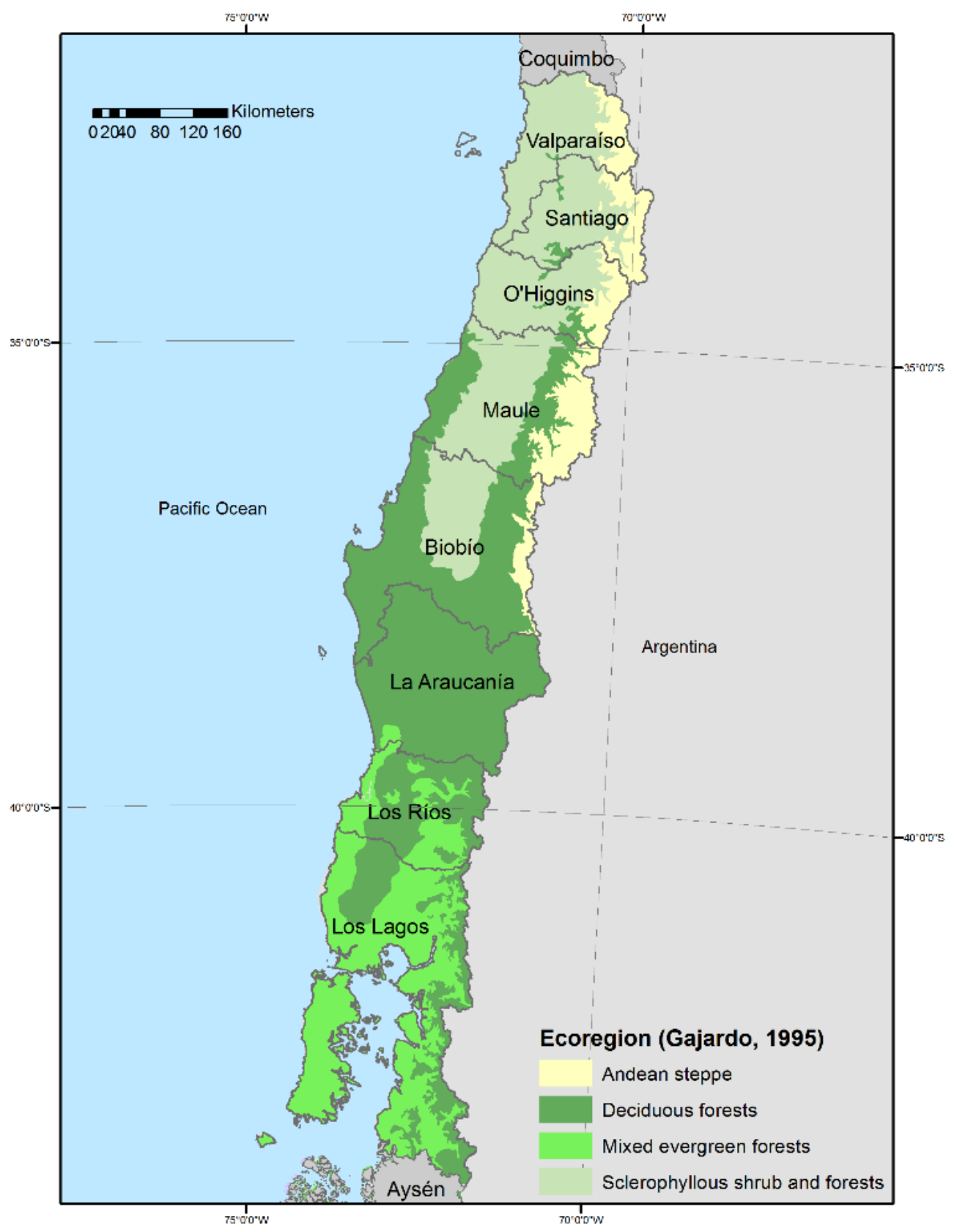


Figure 2: Maps of Chilean land use

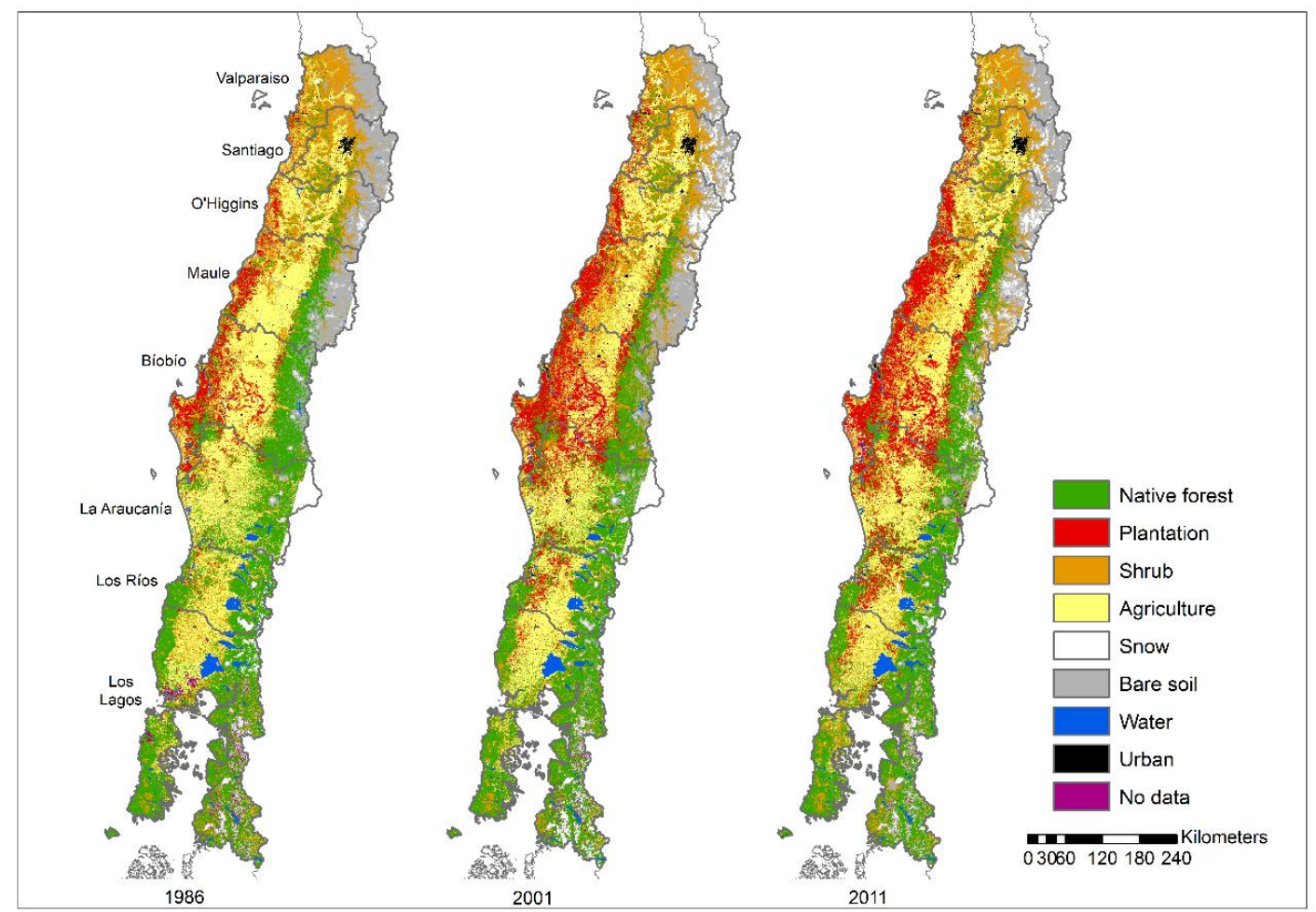

Figure 3: Land use share by region and year

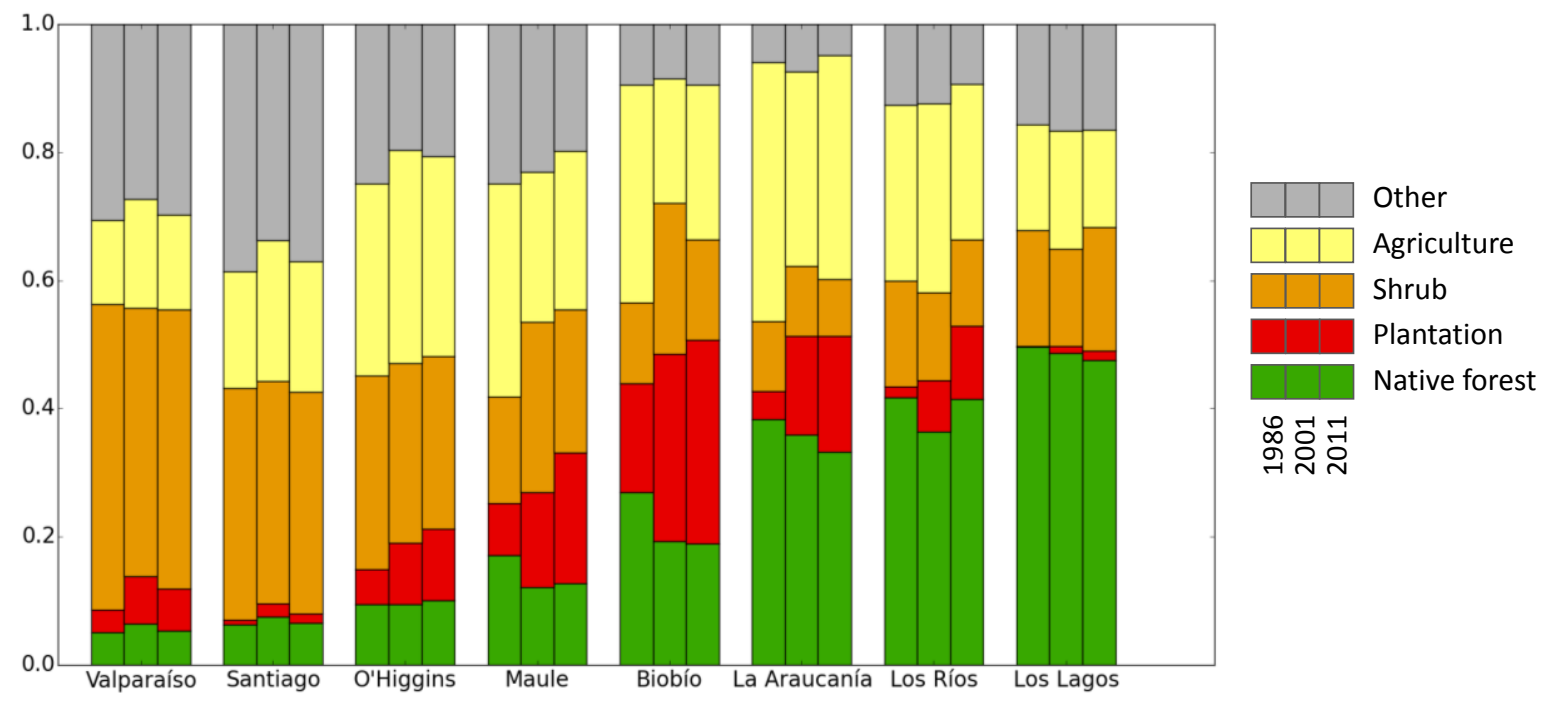



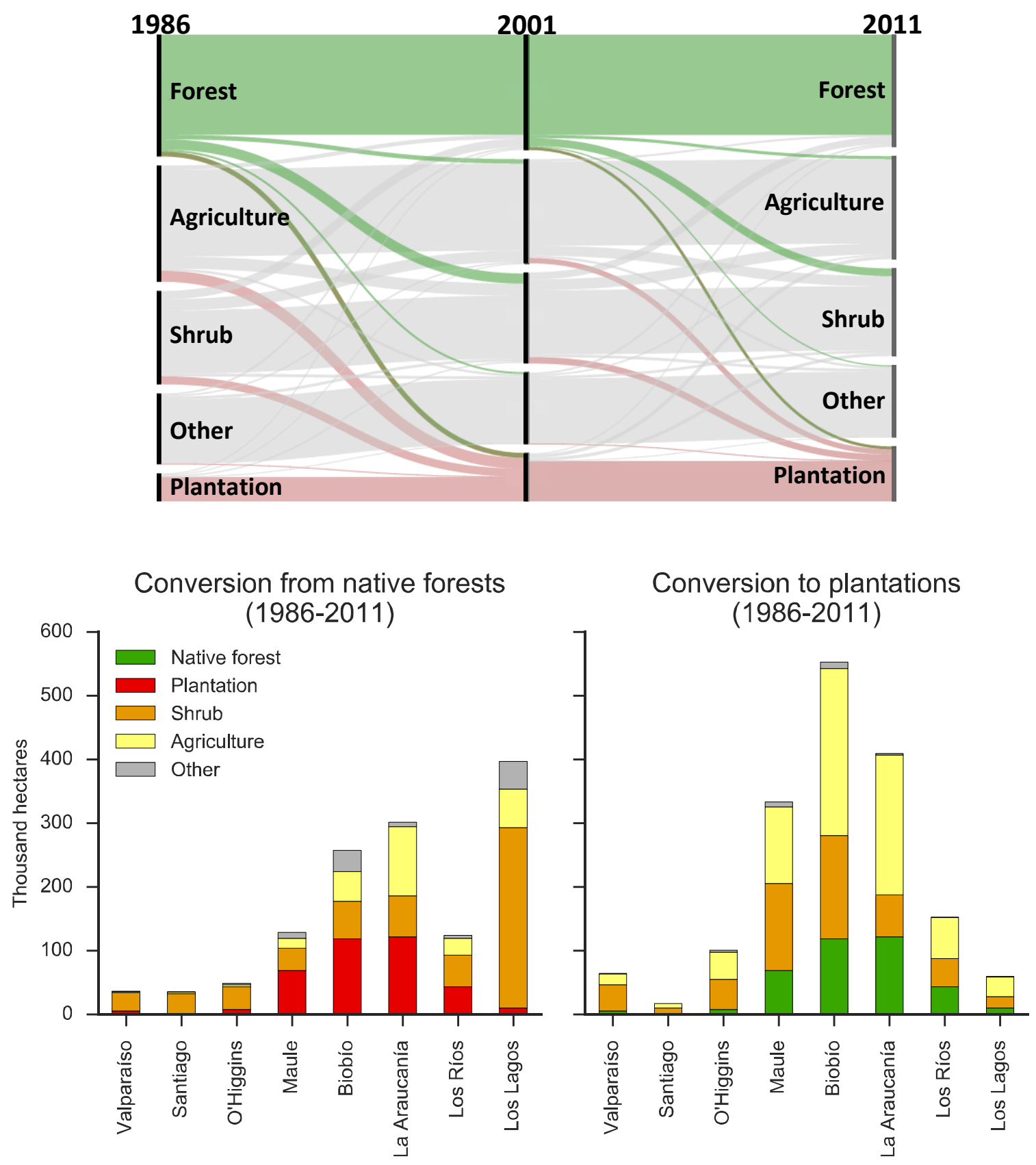


\section{Tables}

Table 1: Land use by time period (thousand ha)

\begin{tabular}{lrrr} 
& 1986 & 2001 & 2011 \\
\hline Native forest & $6039+/-309$ & $5589+/-225$ & $5555+/-244$ \\
Plantation & $1227+/-181$ & $2311+/-272$ & $2884+/-198$ \\
Shrub & $4798+/-380$ & $4991+/-316$ & $3919+/-416$ \\
Agriculture & $4960+/-560$ & $3913+/-428$ & $4594+/-328$ \\
Other & $3732+/-168$ & $3625+/-99$ & $3471+/-141$ \\
No data & 251 & 578 & 586
\end{tabular}

Table 2: Classification confusion matrices (samples)

\begin{tabular}{|c|c|c|c|c|c|c|c|c|}
\hline & & $\begin{array}{l}\text { Native } \\
\text { forest }\end{array}$ & Plantation & Shrub & Agriculture & Other & Total & $\begin{array}{l}\text { Producer's } \\
\text { accuracy }\end{array}$ \\
\hline \multirow{8}{*}{1986} & Native forest & 999 & 11 & 78 & 9 & 6 & 1103 & 0.91 \\
\hline & Plantation & 12 & 128 & 14 & 3 & 3 & 160 & 0.8 \\
\hline & Shrub & 93 & 6 & 565 & 56 & 38 & 758 & 0.75 \\
\hline & Agriculture & 8 & 3 & 26 & 357 & 9 & 403 & 0.89 \\
\hline & Other & 12 & 0 & 25 & 5 & 820 & 862 & 0.95 \\
\hline & Total & 1124 & 148 & 708 & 430 & 876 & 3286 & \\
\hline & User's accuracy & 0.89 & 0.86 & 0.8 & 0.83 & 0.94 & & 0.87 \\
\hline & Карра & 0.83 & & & & & & \\
\hline \multirow{8}{*}{2001} & Native forest & 1415 & 27 & 127 & 25 & 10 & 1604 & 0.88 \\
\hline & Plantation & 37 & 372 & 40 & 20 & 3 & 472 & 0.79 \\
\hline & Shrub & 113 & 49 & 997 & 129 & 40 & 1328 & 0.75 \\
\hline & Agriculture & 7 & 15 & 63 & 606 & 13 & 704 & 0.86 \\
\hline & Other & 7 & 7 & 45 & 27 & 1446 & 1532 & 0.94 \\
\hline & Total & 1579 & 470 & 1272 & 807 & 1512 & 5640 & \\
\hline & User's accuracy & 0.9 & 0.79 & 0.78 & 0.75 & 0.96 & & 0.86 \\
\hline & Карра & 0.81 & & & & & & \\
\hline \multirow{8}{*}{2011} & Native forest & 1226 & 25 & 117 & 11 & 20 & 1399 & 0.88 \\
\hline & Plantation & 25 & 590 & 32 & 12 & 1 & 660 & 0.89 \\
\hline & Shrub & 114 & 21 & 594 & 58 & 36 & 823 & 0.72 \\
\hline & Agriculture & 3 & 13 & 71 & 693 & 11 & 791 & 0.88 \\
\hline & Other & 13 & 7 & 38 & 21 & 961 & 1040 & 0.92 \\
\hline & Total & 1381 & 656 & 852 & 795 & 1029 & 4713 & \\
\hline & User's accuracy & 0.89 & 0.9 & 0.7 & 0.87 & 0.93 & & 0.86 \\
\hline & Карра & 0.82 & & & & & & \\
\hline
\end{tabular}


Table 3: Comparison of annualized rates of forest change derived from different studies

\begin{tabular}{|c|c|c|c|c|}
\hline \multirow[t]{2}{*}{ Study } & \multirow[t]{2}{*}{ Forest type } & \multicolumn{2}{|c|}{ Year } & \\
\hline & & 1987 & 2001 & 2011 \\
\hline \multirow{3}{*}{ Current study } & All forests & 0.56 & 0.66 & \\
\hline & Native forests & -0.51 & -0.06 & \\
\hline & Plantation forests & 4.30 & 2.24 & \\
\hline \multirow{3}{*}{ CONAF, 2011} & All forests & \multicolumn{2}{|c|}{0.38} & \\
\hline & Native forests & \multicolumn{2}{|c|}{0.12} & \\
\hline & Plantation forests & \multicolumn{2}{|c|}{0.97} & \\
\hline Hansen et al., 2013 & All forests & \multicolumn{3}{|c|}{0.18} \\
\hline
\end{tabular}


Appendix A: Imagery used

Table A-1: Path, rows, dates, sensors and cloud cover estimates for all Landsat imagery used in this study

\begin{tabular}{|c|c|c|c|c|c|c|c|c|c|c|}
\hline \multirow[b]{2}{*}{ Path } & \multirow[b]{2}{*}{ Row } & \multicolumn{3}{|c|}{ 1986-era } & \multicolumn{3}{|c|}{ 2001-era } & \multicolumn{3}{|c|}{ 2011-era } \\
\hline & & Date & Sensor & Cloud cover & Date & Sensor & Cloud cover & Date & Sensor & Cloud cover \\
\hline 001 & 085 & $1 / 6 / 1987$ & TM-5 & 0.00 & $1 / 18 / 2000$ & TM-7 & 0.00 & $1 / 8 / 2011$ & TM-5 & 0.25 \\
\hline 001 & 086 & $1 / 6 / 1987$ & TM-5 & 10.00 & $1 / 18 / 2000$ & TM-7 & 0.08 & $1 / 8 / 2011$ & TM-5 & 6.74 \\
\hline 001 & 087 & $12 / 21 / 1986$ & TM-5 & 0.00 & $2 / 21 / 2001$ & TM-7 & 5.48 & $1 / 2 / 2009$ & TM-5 & 0.07 \\
\hline 233 & 082 & 1/28/1986 & TM-5 & 0.15 & 1/13/2001 & TM-7 & 0.48 & $2 / 2 / 2011$ & TM-5 & 0.42 \\
\hline 233 & 083 & $1 / 28 / 1986$ & TM-5 & 0.32 & $1 / 13 / 2001$ & TM-7 & 0.46 & $2 / 2 / 2011$ & TM-5 & 0.13 \\
\hline 233 & 084 & 1/28/1986 & TM-5 & 0.03 & 1/13/2001 & TM-7 & 1.72 & $2 / 2 / 2011$ & TM-5 & 0.03 \\
\hline 233 & 085 & $1 / 15 / 1987$ & TM-5 & 10.00 & $1 / 27 / 2000$ & TM-7 & 0.15 & $1 / 14 / 2010$ & TM-5 & 0.11 \\
\hline 233 & 086 & 1/15/1987 & TM-5 & 0.00 & $1 / 27 / 2000$ & TM-7 & 0.09 & $1 / 14 / 2010$ & TM-5 & 0.06 \\
\hline 233 & 087 & $12 / 30 / 1986$ & TM-5 & 0.97 & $11 / 29 / 2001$ & TM-7 & 0.00 & $2 / 18 / 2011$ & TM-5 & 2.32 \\
\hline 233 & 088 & $9 / 25 / 1986$ & TM-5 & 0.00 & $11 / 29 / 2001$ & TM-7 & 0.03 & $1 / 1 / 2011$ & TM-5 & 10.26 \\
\hline 233 & 089 & $1 / 25 / 1985$ & TM-5 & 0.00 & $10 / 23 / 1999$ & TM-7 & 2.55 & $1 / 1 / 2011$ & TM-5 & 0.02 \\
\hline 233 & 090 & $9 / 25 / 1986$ & TM-5 & 0.00 & $12 / 7 / 2001$ & TM-5 & 0.06 & $1 / 1 / 2011$ & TM-5 & 0.07 \\
\hline 232 & 089 & 3/7/1985 & TM-5 & 0.00 & $2 / 7 / 2001$ & TM-7 & 4.14 & $2 / 19 / 2011$ & TM-7 & 0.14 \\
\hline 232 & 090 & $3 / 7 / 1985$ & TM-5 & 0.00 & $3 / 11 / 2001$ & TM-7 & 7.02 & 2/19/2011 & TM-7 & 0.17 \\
\hline
\end{tabular}




\section{Appendix B: Land use definitions}

Table B-1: Land use class definitions and aggregated categories

\begin{tabular}{|c|c|c|c|}
\hline $\begin{array}{l}\text { Land use } \\
\text { category }\end{array}$ & Land use class & $\begin{array}{l}\text { Land use class - } \\
\quad \text { Spanish }\end{array}$ & Definition \\
\hline \multirow{3}{*}{ Native forest } & $\begin{array}{l}\text { Native adult } \\
\text { forest }\end{array}$ & $\begin{array}{l}\text { Bosque nativo } \\
\text { adulto }\end{array}$ & $\begin{array}{l}\text { Native tree species with a height greater than } 8 \mathrm{~m} \text { and a canopy cover } \\
\text { exceeding } 25 \text { percent of the area. Native adult forests are } \\
\text { usually heterogeneous in terms of vertical structure, age of trees and } \\
\text { canopy size. Adult forests typically have a shrub layer of varying density as } \\
\text { well as a layer of forest regeneration. }\end{array}$ \\
\hline & $\begin{array}{l}\text { Native forest } \\
\text { regrowth }\end{array}$ & Renoval & $\begin{array}{l}\text { Native forest regrowth corresponds to a secondary forest originating either } \\
\text { from seeds and/or vegetative reproduction after a natural or human } \\
\text { disturbance (fire, clearcut, avalanche). In general, trees are homogeneous } \\
\text { in their age, vertical structure and diameters. Native trees with a height } \\
\text { over } 2 \text { meters that cover more than } 25 \% \text { of the area. }\end{array}$ \\
\hline & $\begin{array}{l}\text { Stunted native } \\
\quad \text { forest / } \\
\text { krummholz }\end{array}$ & Achaparrado & $\begin{array}{l}\text { Adult forests with a height of } 2-8 \mathrm{~m} \text {. Krummholz is characterized by slow } \\
\text { growth in height due to unfavorable environmental conditions (e.g. altitude, } \\
\text { low temperatures, strong winds, aridity, poor drainage, shallow soils). }\end{array}$ \\
\hline \multirow{3}{*}{ Plantation } & $\begin{array}{l}\text { Adult } \\
\text { plantations }\end{array}$ & Plantación adulta & $\begin{array}{l}\text { Exotic trees greater than } 3 \text { meters in height cover more than } 25 \text { percent of } \\
\text { the area. Plantations are composed entirely of single age peers, yielding } \\
\text { a very homogeneous forest. }\end{array}$ \\
\hline & $\begin{array}{l}\text { Young } \\
\text { plantation }\end{array}$ & Plantación joven & $\begin{array}{l}\text { Plantation in the early stages of development. This land use corresponds to } \\
\text { a forest layer dominated ( }>25 \% \text { coverage) by exotic or native trees less } \\
\text { than } 3 \text { meters in height. }\end{array}$ \\
\hline & Clear cut & Tala raza & Bare soil that is exposed after plantation clearing. \\
\hline \multirow{3}{*}{ Shrub } & Woody shrub & $\begin{array}{l}\text { Matorral } \\
\text { arborescente }\end{array}$ & $\begin{array}{l}\text { Tree species cover between } 10-25 \text { percent of the area, shrub species cover } \\
10 \text { to } 100 \text { percent of the area and herbaceous species cover between } 0 \text { and } \\
100 \text { percent of the area. }\end{array}$ \\
\hline & Shrub & Matorral & $\begin{array}{l}\text { Tree species cover less than } 10 \text { percent of the area, shrubs cover between } \\
10 \text { and } 100 \text { percent of the area and herbaceous species cover between } 0 \\
\text { and } 100 \text { percent of the area. For this study, it also includes the steppe and } \\
\text { Andean highlands. }\end{array}$ \\
\hline & Wetlands & Humedales & $\begin{array}{l}\text { Water-covered surfaces be they natural or artificial, permanent or } \\
\text { temporary, stagnant or flowing, fresh, brackish or salty. Includes areas } \\
\text { of marine water where the depth of low tide does not exceed } 6 \\
\text { meters. Includes the following categories: permanently flooded } \\
\text { herbaceous vegetation along rivers, seasonally flooded herbaceous } \\
\text { marshes by the sea, peat bogs and wetlands. }\end{array}$ \\
\hline \multirow{3}{*}{ Agriculture } & Crops & Cultivos & $\begin{array}{l}\text { Areas which, at the time of the Landsat image acquisition, were used for } \\
\text { crop production. Crops include cereals, horticulture and fruit production. }\end{array}$ \\
\hline & Fallow & Barbecho & $\begin{array}{l}\text { Bare soil exposed after agricultural harvest and left exposed to fallow a } \\
\text { field. }\end{array}$ \\
\hline & Grassland & Pradera & $\begin{array}{l}\text { Areas where herbaceous species dominate and shrubs and trees cover no } \\
\text { more than } 10 \text { percent of the area. Note that, although high elevation } \\
\text { grasslands such as the Andean Steppe are technically grasslands, we include } \\
\text { them with the shrub class to separate land uses. }\end{array}$ \\
\hline \multirow{4}{*}{ Other } & Snow & Nieve & Areas covered by snow or ice. \\
\hline & Water & Agua & Water bodies including lakes, rivers and oceans. \\
\hline & Urban & Urbano & Areas occupied by cities, industrial facilities or streets. \\
\hline & $\begin{array}{l}\text { Permanently } \\
\text { bare soil }\end{array}$ & $\begin{array}{l}\text { Suelo desnudo } \\
\text { permanente }\end{array}$ & $\begin{array}{l}\text { Areas where the total coverage of all vegetation types (herbs shrubs and } \\
\text { trees) is less than } 25 \% \text {. Bare soils include beaches, dunes, rocky } \\
\text { outcrops, lava runs, landslides not yet colonized by vegetation, salt flats } \\
\text { and river banks. }\end{array}$ \\
\hline
\end{tabular}




\section{References}

Aguayo, Mauricio, Aníbal Pauchard, Gerardo Azócar, and Oscar Parra. 2009. “Cambio Del Uso Del Suelo En El Centro Sur de Chile a Fines Del Siglo XX: Entendiendo La Dinámica Espacial Y Temporal Del Paisaje." Revista Chilena de Historia Natural 82 (3): 361-74. doi:10.4067/S0716078X2009000300004.

Albert, Federico. 1901. Los bosques en el pais, . Santiago de Chile: Imprenta moderna.

- - - 1913. Los bosques, su conservacion, esplotacion i fomento. Kosmos.

Altamirano, Adison, Paul Aplin, Alejandro Miranda, Luis Cayuela, Adam C. Algar, and Richard Field. 2013. "High Rates of Forest Loss and Turnover Obscured by Classical Landscape Measures." Applied Geography 40 (June): 199-211. doi:10.1016/j.apgeog.2013.03.003.

Altamirano, Adison, and A. Lara. 2010. "Deforestation in temperate ecosystems of pre-Andean range of south-central Chile." Bosque 31 (1): 53-64.

Angelsen, Arild. 2008. "REDD Models and Baselines." International Forestry Review 10 (3): 465-75. doi:10.1505/ifor.10.3.465.

Angelsen, Arild, and Thomas K. Rudel. 2013. "Designing and Implementing Effective REDD + Policies: A Forest Transition Approach." Review of Environmental Economics and Policy 7 (1): 91-113. doi:10.1093/reep/res022.

Balthazar, Vincent, Veerle Vanacker, and Eric F. Lambin. 2012. "Evaluation and Parameterization of ATCOR3 Topographic Correction Method for Forest Cover Mapping in Mountain Areas." International Journal of Applied Earth Observation and Geoinformation 18 (August): 436-50. doi:10.1016/j.jag.2012.03.010.

Barlow, J., T. A. Gardner, I. S. Araujo, T. C. Ávila-Pires, A. B. Bonaldo, J. E. Costa, M. C. Esposito, et al. 2007. "Quantifying the Biodiversity Value of Tropical Primary, Secondary, and Plantation Forests." Proceedings of the National Academy of Sciences 104 (47): 18555-60. doi:10.1073/pnas.0703333104.

Becerra, Pablo I, and Javier A Simonetti. 2013. "Patterns of Exotic Species Richness of Different Taxonomic Groups in a Fragmented Landscape of Central Chile." Bosque (Valdivia) 34 (1): 11-12. doi:10.4067/S0717-92002013000100006.

Bruggeman, Derek, Patrick Meyfroidt, and Eric F. Lambin. 2016. "Forest Cover Changes in Bhutan: Revisiting the Forest Transition." Applied Geography 67 (February): 49-66. doi:10.1016/j.apgeog.2015.11.019.

Bryant, Dirk, Daniel Nielsen, and Laura Tangley. 1997. "The Last Frontier Forests: Ecosystems \& Economies on the Edge." World Resources Institute.

Camus, Pablo, and María Eugenia Solari. 2008. "La Invención de La Selva Austral: Bosques Y Tierras Despejadas En La Cuenca Del Río Valdivia (siglos XVI-XIX)." Revista de Geografía Norte Grande, no. 40 (September): 5-22. doi:10.4067/S0718-34022008000200001.

Carle, Jim, Petteri Vuorinen, and Alberto Del Lungo. 2002. "Status and Trends in Global Forest Plantation Development." Forest Products Journal 52 (7/8): 12-23.

Carmona, A., and L. Nahuelhual. 2012. "Combining Land Transitions and Trajectories in Assessing Forest Cover Change." Applied Geography 32 (2): 904-15. doi:10.1016/j.apgeog.2011.09.006.

CIREN. 2013. "Informe Técnical Final: Proyecto Monitoreo de Cambios, Correción Cartográfica Y Actualización Del Catastro de Bosque Native En Las Regions de Valparaíso, Metropolitana Y Libertador Bernardo O'Higgins."

Clapp, Roger A. 1995. "Creating Competitive Advantage: Forest Policy as Industrial Policy in Chile." Economic Geography 71 (3): 273-96.

- - . 1998. "Waiting for the Forest Law: Resource-Led Development and Environmental Politics in Chile." Latin American Research Review 33 (2). 
- - . 2001. "Tree Farming and Forest Conservation in Chile: Do Replacement Forests Leave Any Originals Behind?" Society \& Natural Resources 14 (4): 341-56.

CONAF. 2008. "Catastro de Uso Del Suelo Y Vegetación."

- - . 2011. "Catastro de Los Recursos Vegetacionales Nativos de Chile: Monitoreo de Cambios Y Actualizaciones, Periodo 1997-2011." Corporacion Nacional Forestal.

CONAF, and CONAMA-BIRF. 1995. "Manual de Terreno. Proyecto Catastro Y Evaluación de Los Recursos Vegetacionales Nativos de Chile." Santiago.

CONAF, CONAMA, and BIRF. 1999. "Catastro Y Evaluacion de Recursos Vegetacionales Nativos de Chile." CONAF, and Universidad Austral de Chile. 2014. "Monitoreo de Cambios, Corrección Cartográfica Y Actualización Del Catastro de Los Recursos Vegetacionales Nativos de La Región de Los Ríos."

Congalton, Russell G., and Kass Green. 2009. Assessing the Accuracy of Remotely Sensed Data: Principles and Practices. CRC Press.

Coppin, P., I. Jonckheere, K. Nackaerts, B. Muys, and Eric F. Lambin. 2004. "Digital Change Detection Methods in Ecosystem Monitoring: A Review." International Journal of Remote Sensing 25 (9): 1565-96. doi:10.1080/0143116031000101675.

Crist, Eric P. 1985. "A TM Tasseled Cap Equivalent Transformation for Reflectance Factor Data." Remote Sensing of Environment 17 (3): 301-6. doi:16/0034-4257(85)90102-6.

de Jong, Wil. 2010. "Forest Rehabilitation and Its Implication for Forest Transition Theory." Biotropica 42 (1): 3-9. doi:10.1111/j.1744-7429.2009.00568.x.

Diaz, G. Ignacio, L. Nahuelhual, C. Echeverria, and S. Marin. 2010. "Drivers of Land Abandonment in Southern Chile and Implications for Landscape Planning." Landscape and Urban Planning.

Echeverria, Cristian, David Coomes, Javier Salas, José María Rey-Benayas, Antonio Lara, and Adrian Newton. 2006. "Rapid Deforestation and Fragmentation of Chilean Temperate Forests." Biological Conservation 130 (4): 481-94. doi:10.1016/j.biocon.2006.01.017.

Echeverría, Cristian, Adrian Newton, Laura Nahuelhual, David Coomes, and José María Rey-Benayas. 2012. "How Landscapes Change: Integration of Spatial Patterns and Human Processes in Temperate Landscapes of Southern Chile." Applied Geography 32 (2): 822-31. doi:10.1016/j.apgeog.2011.08.014.

FAO. 2010a. "Evaluación de Los Recursos Forestales Mundiales 2010. Informe Final: Chile." Rome.

- - . 2010b. "Global Forest Resource Assessment 2010." United Nations Food and Agriculture Organization (FAO).

- - - 2011. "State of the World's Forests 2011." Rome: Food and Agriculture Organization of the United Nations.

Favero, Alice, and Robert Mendelsohn. 2014. "Using Markets for Woody Biomass Energy to Sequester Carbon in Forests." Journal of the Association of Environmental and Resource Economists 1 (1): 75-95. doi:10.1086/676033.

Foster, Andrew D., and Mark R. Rosenzweig. 2003. "Economic Growth And The Rise Of Forests*." Quarterly Journal of Economics 118 (2): 601-37. doi:i: 10.1162/003355303321675464</p>.

Frank, Dorothea, and Manfred Finckh. 1997. "Impactos de Las Plantaciones de Pino Oregón Sobre La Vegetación Y El Suelo En La Zona Centro-Sur de Chile." Revista Chilena de Historia Natural 70: 191-211.

Fredes, M. 2002. "Report on Chile's Government Information about Plantation of Exotic Species in Region X." Santiago, Chile: Centro Austral de Derecho Ambiental (CEADA).

Gao, F., J. G Masek, and R. E Wolfe. 2009. "Automated Registration and Orthorectification Package for Landsat and Landsat-like Data Processing." Journal of Applied Remote Sensing 3 (033515): 033515.

Gayoso, Jorge. 2001. "Medición de La Capacidad de Captura de Carbono En Bosques Nativos Y Plantaciones de Chile." Trabajo Presentado En El Taller Secuestro de Carbono. Mérida, 
Venezuela. Universidad Austral de Chile.

http://aprobosque.cl/Documentos/Docum_tecnicos/1754uesnativos.pdf.

Gonzalez, Ricardo. 2010. "Econometric Modeling of Land-Use Changes in Southern Chile." Universidad Austral de Chile.

Haig, Irvine, L.V. Teesdale, Philip Briegleb, Burnett Payne, and Martin Haertel. 1946. Forest Resources of Chile as a Basis for Industrial Expansion. Washington: Forest Service, U.S. Dept. of Agriculture.

Hall, Jaclyn M., Tracy Van Holt, Amy E. Daniels, Vincent Balthazar, and Eric F. Lambin. 2012. "Trade-Offs between Tree Cover, Carbon Storage and Floristic Biodiversity in Reforesting Landscapes." Landscape Ecology 27 (8): 1135-47. doi:10.1007/s10980-012-9755-y.

Hansen, M. C., P. V. Potapov, R. Moore, M. Hancher, S. A. Turubanova, A. Tyukavina, D. Thau, et al. 2013. "High-Resolution Global Maps of 21st-Century Forest Cover Change." Science 342 (6160): 850-53. doi:10.1126/science.1244693.

Heilmayr, Robert. 2015. "Chile's Forest Transition Foreshadowing Changes in Global Timber Markets and Governance." Stanford University.

Heilmayr, Robert, and Eric F. Lambin. 2016. "Impacts of Nonstate, Market-Driven Governance on Chilean Forests." Proceedings of the National Academy of Sciences 113 (11): 2910-15. doi:10.1073/pnas.1600394113.

Henne, Adam, and Teena Gabrielson. 2012. "Chile Is Timber Country." Environment and Citizenship in Latin America: Natures, Subjects and Struggles 101: 149.

Holt, Tracy Van, Carlos A. Moreno, Michael W. Binford, Kenneth M. Portier, Sandor Mulsow, and Thomas K. Frazer. 2012. "Influence of Landscape Change on Nearshore Fisheries in Southern Chile." Global Change Biology 18 (7): 2147-60. doi:10.1111/j.1365-2486.2012.02674.x.

INFOR. 1986a. "Estadísticas Forestales." Estadísticas Forestales.

- - . 1986b. Inventario de las plantaciones forestales de la X región: informe final. INFOR.

- - . 2009. "Inventario Continuo de Bosques Nativos Y Actualizacion de Plantaciones Forestales."

INFOR, and CORFO. 1996. "Estadísticas Forestales." Estadísticas Forestales.

Jackson, Robert B., Esteban G. Jobbágy, Roni Avissar, Somnath Baidya Roy, Damian J. Barrett, Charles W. Cook, Kathleen A. Farley, David C. le Maitre, Bruce A. McCarl, and Brian C. Murray. 2005. "Trading Water for Carbon with Biological Carbon Sequestration." Science 310 (5756): 1944-47. doi:10.1126/science.1119282.

Lambin, Eric F., and Patrick Meyfroidt. 2010. "Land Use Transitions: Socio-Ecological Feedback versus Socio-Economic Change." Land Use Policy.

Lambin, Eric F., and Alan H. Strahler. 1994. "Change-Vector Analysis in Multitemporal Space: A Tool to Detect and Categorize Land-Cover Change Processes Using High Temporal-Resolution Satellite Data." Remote Sensing of Environment 48 (2): 231-44. doi:16/0034-4257(94)90144-9.

La Nación. 2011. "Polémica Por Superficie Real Del Bosque Nativo En El País," July 11. http://www.lanacion.cl/noticias/site/artic/20110711/pags/20110711191031.html.

Lara, Antonio, María Eugenia Solari, María Del Rosario Prieto, and María Paz Peña. 2012. "Reconstrucción de La Cobertura de La Vegetación Y Uso Del Suelo Hacia 1550 Y Sus Cambios a 2007 En La Ecorregión de Los Bosques Valdivianos Lluviosos de Chile ( $\left.35^{\circ}-43^{\circ} 30 \mathrm{~S}\right)$." Bosque (Valdivia) 33 (1): 13-23.

Lara, Antonio, and T. Veblen. 1993. "Forest Plantations in Chile: A Successful Model?" In Afforestation: Policies, Planning and Progress, by A. S. Mather.

Li, Hongmei, T. Mitchell Aide, Youxin Ma, Wenjun Liu, and Min Cao. 2006. "Demand for Rubber Is Causing the Loss of High Diversity Rain Forest in SW China." Biodiversity and Conservation 16 (6): 1731-45. doi:10.1007/s10531-006-9052-7. 
Little, C., A. Lara, J. McPhee, and R. Urrutia. 2009. "Revealing the Impact of Forest Exotic Plantations on Water Yield in Large Scale Watersheds in South-Central Chile." Journal of Hydrology 374 (1-2): 162-70. doi:10.1016/j.jhydrol.2009.06.011.

Masek, J. G, E. F Vermote, N. E Saleous, R. Wolfe, F. G Hall, K. F Huemmrich, Feng Gao, J. Kutler, and Teng-Kui Lim. 2006. "A Landsat Surface Reflectance Dataset for North America, 1990-2000." IEEE Geoscience and Remote Sensing Letters 3 (1): 68-72. doi:10.1109/LGRS.2005.857030.

Mather, A. S. 1992. "The Forest Transition." Area 24 (4): 367-79.

Mather, A. S., and J. Fairbairn. 2000. "From Floods to Reforestation: The Forest Transition in Switzerland." Environment and History 6 (November): 399-421. doi:10.3197/096734000129342352.

Mather, A. S., J. Fairbairn, and C. L. Needle. 1999. "The Course and Drivers of the Forest Transition: The Case of France." Journal of Rural Studies 15 (1): 65-90. doi:10.1016/S0743-0167(98)00023-0.

Meyer, Peter, Klaus I. Itten, Tobias Kellenberger, Stefan Sandmeier, and Ruth Sandmeier. 1993. "Radiometric Corrections of Topographically Induced Effects on Landsat TM Data in an Alpine Environment." ISPRS Journal of Photogrammetry and Remote Sensing 48 (4): 17-28. doi:10.1016/0924-2716(93)90028-L.

Meyfroidt, Patrick, and Eric F. Lambin. 2008. "The Causes of the Reforestation in Vietnam." Land Use Policy 25 (2): 182-97.

- - . 2011. "Global Forest Transition: Prospects for an End to Deforestation." Annual Review of Environment and Resources 36 (1): 343-71. doi:10.1146/annurev-environ-090710-143732.

Meyfroidt, Patrick, Thomas K. Rudel, and Eric F. Lambin. 2010. "Forest Transitions, Trade, and the Global Displacement of Land Use." Proceedings of the National Academy of Sciences 107 (49): 2091722. doi:10.1073/pnas.1014773107.

Miranda, Alejandro, Adison Altamirano, Luis Cayuela, Francoise Pincheira, and Antonio Lara. 2015. "Different Times, Same Story: Native Forest Loss and Landscape Homogenization in Three Physiographical Areas of South-Central of Chile." Applied Geography 60 (June): 20-28. doi:10.1016/j.apgeog.2015.02.016.

Modrego, Felix, Daniel Barrera, and Romain Charnay. 2004. "Estimacion Del Effecto Del Decreto Ley N 701 de Fomento Forestal Sobre Las Tasas de Forestación En Chile: Un Análisis a Nivel Regional." Working Paper.

Nagendra, Harini, and Jane Southworth. 2009. Reforesting Landscapes: Linking Pattern and Process. 1st ed. Springer.

Nahuelhual, Laura, Alejandra Carmona, Antonio Lara, Cristian Echeverría, and Mauro E. González. 2012. "Land-Cover Change to Forest Plantations: Proximate Causes and Implications for the Landscape in South-Central Chile." Landscape and Urban Planning 107 (1): 12-20. doi:10.1016/j.landurbplan.2012.04.006.

Nepstad, Daniel, Britaldo S. Soares-Filho, Frank Merry, André Lima, Paulo Moutinho, John Carter, Maria Bowman, et al. 2009. "The End of Deforestation in the Brazilian Amazon." Science 326 (5958): 1350-51. doi:10.1126/science.1182108.

Niklitschek, Mario E. 2007. "Trade Liberalization and Land Use Changes: Explaining the Expansion of Afforested Land in Chile." Forest Science 53 (3): 385-94.

Olofsson, Pontus, Giles M. Foody, Stephen V. Stehman, and Curtis E. Woodcock. 2013. "Making Better Use of Accuracy Data in Land Change Studies: Estimating Accuracy and Area and Quantifying Uncertainty Using Stratified Estimation." Remote Sensing of Environment 129 (February): 12231. doi:10.1016/j.rse.2012.10.031.

Otero, Luis. 2006. La huella del fuego: historia de los bosques nativos : poblamiento y cambios en el paisaje del sur de Chile. Pehuén Editores Limitada. 
Oyarzun, C. E., and L. Peña. 1995. "Soil Erosion and Overland Flow in Forested Areas with Pine Plantations at Coastal Mountain Range, Central Chile." Hydrological Processes 9 (1): 111-18. doi:10.1002/hyp.3360090110.

Perz, Stephen G. 2007. "Grand Theory and Context-Specificity in the Study of Forest Dynamics: Forest Transition Theory and Other Directions." The Professional Geographer 59 (1): 105. doi:10.1111/j.1467-9272.2007.00594.x.

Richardson, David M. 1998. "Forestry Trees as Invasive Aliens." Conservation Biology 12 (1): 18-26. doi:10.1111/j.1523-1739.1998.96392.x.

Rosenthal, Elisabeth. 2010. "Deforestation Slows as Brazil Chugs Toward a Goal." New York Times, December 2. http://green.blogs.nytimes.com/2010/12/02/deforestation-slows-as-brazil-chugstoward-a-goal/.

Rudel, Thomas K. 2009. "Tree Farms: Driving Forces and Regional Patterns in the Global Expansion of Forest Plantations." Land Use Policy 26 (3): 545-50. doi:10.1016/j.landusepol.2008.08.003.

Rudel, Thomas K., Oliver Coomes, Emilio Moran, Frederic Achard, Arild Angelsen, Jianchu Xu, and Eric F. Lambin. 2005. "Forest Transitions: Towards a Global Understanding of Land Use Change." Global Environmental Change 15: 23-31.

Schulz, J. J, L. Cayuela, C. Echeverria, J. Salas, and J. M.R Benayas. 2010. "Monitoring Land Cover Change of the Dryland Forest Landscape of Central Chile (1975-2008)." Applied Geography 30: 436-47.

Sedjo, Roger A., and Daniel Botkin. 1997. "Using Foret Plantations TO SPARE Natural Forests." Environment: Science and Policy for Sustainable Development 39 (10): 14-30. doi:10.1080/00139159709604776.

Silva, Eduardo. 2007. "The Import-Substitution Model Chile in Comparative Perspective." Latin American Perspectives 34 (3): 67-90. doi:10.1177/0094582X07300589.

Smith-Ramírez, Cecilia. 2004. "The Chilean Coastal Range: A Vanishing Center of Biodiversity and Endemism in South American Temperate Rainforests." Biodiversity \& Conservation 13 (2): 37393. doi:10.1023/B:BIOC.0000006505.67560.9f.

Stehman, Stephen V., and James D. Wickham. 2011. "Pixels, Blocks of Pixels, and Polygons: Choosing a Spatial Unit for Thematic Accuracy Assessment." Remote Sensing of Environment In Press, Corrected Proof. doi:16/j.rse.2011.06.007.

Stephens, S. Sky, and Michael R. Wagner. 2007. "Forest Plantations and Biodiversity: A Fresh Perspective." Journal of Forestry 105 (6): 307-13.

Strengers, Bart J., Jelle G. Minnen, and Bas Eickhout. 2007. "The Role of Carbon Plantations in Mitigating Climate Change: Potentials and Costs." Climatic Change 88 (November): 343-66. doi:10.1007/s10584-007-9334-4.

Teillet, P.M., B. Guindon, and D. Goodenough. 1981. "On the Slope-Aspect Correction of Multispectral Scanner Data." LARS Symposia, January. http://docs.lib.purdue.edu/lars_symp/444.

USGS. 2008. "Global Land Survey Digital Elevation Model (GLSDEM).” Global Land Cover Facility, University of Maryland.

van Noordwijk, Meine, and Grace B. Villamor. 2014. "Tree Cover Transitions in Tropical Landscapes: Hypotheses and Cross-Continental Synthesis." GLP News, no. 10: 33-37.

Walker, Robert. 2012. "The Scale of Forest Transition: Amazonia and the Atlantic Forests of Brazil." Applied Geography, Environmental Kuznets Curves and Environment-Development Research, 32 (1): 12-20. doi:10.1016/j.apgeog.2010.10.010.

Xu, Jianchu. 2011. “China's New Forests Aren't as Green as They Seem.” Nature 477 (7365): 371-371. doi:10.1038/477371a. 